\title{
Evaluation of rapeseed-mustard cultivars under late sown condition in coastal ecosystem of West Bengal
}

\author{
Hirak Banerjee ${ }^{1 *}$, Soumitra Chatterjee ${ }^{2}$, Sukamal Sarkar ${ }^{3}$, Saikat Gantait ${ }^{4}$ and Subhasis \\ Samanta ${ }^{1}$ \\ ${ }^{1}$ Regional Research Station (CSZ), Bidhan Chandra Krishi Viswavidyalaya, Kakdwip, South 24-Parganas - 743347 \\ (West Bengal), INDIA \\ ${ }^{2}$ All India Coordinated Research Project on IFS, Bidhan Chandra Krishi Viswavidyalaya, Directorate of Research, \\ Kalyani-741235 (West Bengal) INDIA \\ ${ }^{3}$ Department of Agronomy, Faculty of Agriculture, Bidhan Chandra Krishi Viswavidyalaya, Mohanpur- 741252, \\ (West Bengal) INDIA \\ ${ }^{4}$ All India Coordinated Research Project on Groundnut, Bidhan Chandra Krishi Viswavidyalaya, Directorate of \\ Research, Kalyani- 741235, (West Bengal) INDIA \\ *Corresponding author. E-mail: hirak.bckv@gmail.com
}

Received: October 2, 2016; Revised received: February 6, 2017; Accepted: April 30, 2017

\begin{abstract}
In our present report, we evaluated seven rapeseed mustard cultivars at coastal saline zone of West Bengal, India under rice-mustard sequence in a triplicated randomized block design for 14 traits to study their performance under late sown ( $2^{\text {nd }}$ December) condition. The cultivars were sown at $30 \mathrm{~cm} \times 10 \mathrm{~cm}$ spacing during winter of 2013-14 and 2014-15. The soil was clay in texture and had the following key properties for the 0-30 cm layer: $\mathrm{pH} 5.84$, electrical conductivity (EC) $1.55 \mathrm{dS} / \mathrm{m}$, available nitrogen $(\mathrm{N}) 155.24 \mathrm{~kg} / \mathrm{ha}$, available phosphorus $(\mathrm{P})$ $105.76 \mathrm{~kg} / \mathrm{ha}$, available potassium (K) $365.86 \mathrm{~kg} / \mathrm{ha}$ and available B $2.63 \mathrm{~kg} / \mathrm{ha}$. Among the seven cultivars, Kranti produced significantly $(p \leq 0.05)$ higher seed yield $(1.33 \mathrm{t} / \mathrm{ha})$ closely followed by the hybrids PAC $-409(1.23 \mathrm{t} / \mathrm{ha})$ and Pusa Bold $(1.21 \mathrm{t} / \mathrm{ha})$. Seed yield showed significant $(p \leq 0.05)$ positive correlation with all the independent variables (plant height, $\mathrm{R}^{2}=0.88$; dry matter, $\mathrm{R}^{2}=0.42$; days to $50 \%$ flowering, $\mathrm{R}^{2}=0.27$; number of siliqua/plant, $\mathrm{R}^{2}=0.38$; seeds/siliqua, $R^{2}=0.48$; except number of fertile plants $/ \mathrm{m}^{2}, R^{2}=-0.06$; number of secondary branches/plant, $R^{2}=-0.97$ and length of siliqua, $\left.R^{2}=-0.07\right)$. However, number of secondary branches/plant had significant $(p \leq 0.05)$ and negative correlation with seed yield of mustard $\left(R^{2}=-0.97\right)$. Plant height revealed the highest degree of correlation $\left(R^{2}=0.88\right)$ with seed yield followed by siliqua per main branch $\left(R^{2}=0.77\right)$, days to harvest $\left(R^{2}=0.75\right)$ and 1000 -seed weight $\left(R^{2}=0.52\right)$. The results indicated that selection of suitable rapeseed mustard cultivars based on these traits would be more effective in improving seed yield in mustard.
\end{abstract}

Keywords: Correlation, Path coefficient analysis, Saline soil, Seed yield

\section{INTRODUCTION}

Rapeseed-mustard is one of the most important oilseed crops of India which is grown on an area of 6.70 million ha with 7.88 million $\mathrm{t}$ production and the productivity of $1188 \mathrm{~kg} / \mathrm{ha}$ (Crop Production Statistics Information System, 2016). In West Bengal, it is grown under sub-tropical climate as a cold weather crop under irrigated or restricted irrigated condition (Ray et al., 2015) where the state contributes only 6.07 $\%$ to the national production (Economic Review, 2015). Mustard sown in lines can benefit by irrigation, where irrigation is applied by providing channels in between two adjacent rows. Normally, 2 irrigations are recommended, one at rosette stage (20-30 DAS) and another at siliqua formation stage (50-60 DAS). The productivity of the crop in the state $(1066 \mathrm{~kg} / \mathrm{ha})$ is quite lower than developed countries mainly due to cultivation of age-old varieties having low yield potential (De et al., 2014, Directorate of Agriculture, 2014-15). The productivity is also constrained further due to its cultivation in the soil with residual or marginal fertility, and conserved soil moisture (Ray et al., 2016). Contrarily, improved agro- techniques like use of improved cultivars, timely sowing, ridge and furrow sowing method, adequate nutrient supply, irrigation at critical stages, chemical weed management at critical period (15-40 DAS) and use of plant growth regulators (PGR) are the keys to achieve higher productivity of the crop in developed countries under fertile land situation. However, the trend of rapeseed-mustard cultivation in the state all together has been increasing during the last five years, the reason being the adoption of varieties with improved yielding ability. Considering the demand-supply gap of edible oil in West Bengal, still there is huge growth potential in this segment. 
Since rapeseed-mustard is grown in resource-scarce regions of the state, their contribution to livelihood security to the small and marginal farmers in coastal region is also very important. In coastal areas of West Bengal, farmers grow mostly low yielding traditional rainfed or long duration high yielding varieties (145-150 days) of rice during wet season, leaving most of the lands fallow during dry season (monocropping). Growing of rapeseed-mustard as a second crop in rice-based system could bring an additional net income of Rs. 23127/- per hectare per annum following standard package of practice (Singh et al., 2010). Lack of good quality irrigation water and modern agro-techniques are some of the reasons for which growing a second crop is limited. In some cases, immediately after harvesting of kharif rice, heavy moisture status of clay soil provide hindrance towards the sowing of next crop at optimum time (Ray et al., 2014a). Hence, there is an urgent need for diversification and intensification of rice-based cropping system that can improve the productivity and profitability per unit area per unit time without jeopardizing the soil health (Shah et al., 2015). Cultural management practices such as selection of cultivars, planting time and duration of cultivar's life cycle are the key factors influencing the growth and yield of crop (Sheoran et al., 2014). Hence, it is a challenge to identify a suitable cultivar of rapeseedmustard crop that could perform well under delayed sowing (beyond November after harvesting of kharif rice) in coastal saline zone of West Bengal, particularly under assured irrigation and NPK fertilization.

Seed yield of rapeseed-mustard, a complex dependent character, is contributed by a number of component characters (Ray et al., 2014b). Thus, direct selection of a cultivar for seed yield is often not very effective rather indirect selection based on some associated traits may be useful (Hassan et al., 2013). Understanding the nature of associations among traits is important for direct or indirect selection and consequently to improve the efficiency of selection gains in plant breeding programs (Shimelis and Hugo, 2011). Simple correlation analysis establishes the mutual associations of variables without regard to cause and effect. Path coefficient analysis is useful statistical procedures to estimate the magnitude and nature of associations between selection parameters (Mashilo et al., 2016). With this background information, the present study was carried out for consecutive two years under coastal ecosystem of West Bengal for understanding the variation in growth and yield-determining traits of rapeseed-mustard under late sown condition.

\section{MATERIALS AND METHODS}

Study area: Field trials were set up at the Regional Research Station (RRS) (Coastal Saline Zone) of Bidhan Chandra Krishi Viswavidyalaya (BCKV), situated at the south-eastern part of the state $\left(22^{\circ} 40^{\prime} \mathrm{N}\right.$ latitude, $88^{\circ} 18^{\prime} \mathrm{E}$ longitude and $7 \mathrm{~m}$ above mean sea level) at Kakdwip, South 24-Parganas, West Bengal. The region belongs to the sub-humid and sub-tropical agro-ecological zone with an average annual rainfall of $1560 \mathrm{~mm}, 80 \%$ of which falls during the rainy season (June-September) due to the southwest monsoon. Weather data were logged at Automated Weather Station (AWS), RRS, BCKV, Kakdwip during the growing season (December to March) in 2013-14 and 2014-15 (Table 1). Maximum and minimum temperature fluctuated between 24.4-31.8 and 11.5-20.6 ${ }^{\circ} \mathrm{C}$ during winter $2013-14$, while $24.9-32.1$ and $12.3-20.5{ }^{\circ} \mathrm{C}$ during winter 2014-15. Average relative humidity prevailed between $86.7-88.3$ and 73.4-78.2 \% during winter 2012-13 and 2013-14, respectively. There was no rain during $1^{\text {st }}$ year cropping while the rainfall during $2^{\text {nd }}$ year was recorded $36.6 \mathrm{~mm}$. The soil was having clay in texture and had the following key properties for the $0-30 \mathrm{~cm}$ layer: pH 5.84 (in 1:2.5:: Soil : Water), EC $1.55 \mathrm{dS} / \mathrm{m}$ (in 1:2.5:: Soil : Water), available N $155.24 \mathrm{~kg} / \mathrm{ha}$ (Hot alkaline $\mathrm{KMnO}_{4}$ Method), available $\mathrm{P} 105.76 \mathrm{~kg} / \mathrm{ha}$ (0.5 M NaHCO 3 extract), available $\mathrm{K} 365.86 \mathrm{~kg} / \mathrm{ha}$ (Neutral $\mathrm{N} \mathrm{NH}_{4} \mathrm{OAc}$ extract) and available B $2.63 \mathrm{~kg} /$ ha (Hot water-CaCl${ }_{2}$ extraction described by Berger and Truog, 1939).

Experimental design and crop management: Seven rapeseed-mustard cultivars (Table 2) were evaluated under rice-mustard sequence in a triplicated randomized block design for 14 traits to study their performance under late sown condition. Seeds were hand-placed in moist horizon under line sowing @ 5 $\mathrm{kg} / \mathrm{ha}$ with a spacing of $30 \mathrm{~cm} \times 10 \mathrm{~cm}$ on $2^{\text {nd }}$ December during both the years of study. Thinning was practiced at 20 days after sowing (DAS) to maintain optimum plant population per unit area. Phosphorus (40 kg/ha) as single super phosphate and potassium (40 kg/ha) as muriate of potash were applied basal at the time of final land preparation. Nitrogen ( 80 $\mathrm{kg} / \mathrm{ha}$ ) as urea was given in two equal splits namely, half $\mathrm{N}$ as basal (at the time of final land preparation) and rest half $\mathrm{N}$ at 25 DAS (after completion of first weeding). The size of the individual plot was $5 \mathrm{~m} \times$ $4 \mathrm{~m}$. Three irrigations were imposed based on critical phonological growth stages viz. active growth stage (at 20 DAS), siliqua development stage (at 40 DAS) and grain filling stage (60 DAS). Confidor (Imidacloprid) $17.8 \%$ SL was applied @4 ml/10 l of water at 40 DAS particularly against sucking insects like aphids, jassids, thrips etc. Single spray of Actara (Thiamethoxam) 25 \%WG@5 g/15 1 of water was given at 50 DAS to protect the crop against a broad spectrum of sucking pests. Two sprays of Tarzan (Triazophos) $40 \%$ EC was done@1.5 ml/l of water at 50 and 70 DAS to check whitefly and leaf miner attack. 
Measurements of crop parameters: Five randomly selected plants in each plot were uprooted and cleaned, and observations on growth parameters (height, dry matter, secondary branches/plant, tertiary branches/ plant and length of stem upto starting point of siliqua) were recorded to obtain mean data. Yield attributes were recorded at harvest to assess the contribution towards yield. The seeds/siliqua was the average of 10 randomly selected siliqua from 5 plants. The seed and stover yield were computed from the harvest of the net plots at $14 \%$ moisture basis by using the following formula and data were presented as $\mathrm{t} / \mathrm{ha}$.

$\mathrm{Y}=$ [plot yield $(\mathrm{kg}) /$ plot size $\left.\left(\mathrm{m}^{2}\right)\right] \times 10000 \times$ [(100-M)/(100-14)]

Where, $\mathrm{Y}=$ seed/stover yield in $\mathrm{t} / \mathrm{ha}$ and $\mathrm{M}=$ moisture content of seed (\%) at the time of taking weight

Statistical analysis: The collected data were analyzed statistically by the analysis of variance (ANOVA) technique using the SAS 9.3 version (SAS Institute Inc., 2011). The ANOVA of rapeseed-mustard yield across the years revealed a non-significant variation within the years as well as year $\times$ cultivar interactions at $p \leq 0.05$. The homogeneity of error variance was

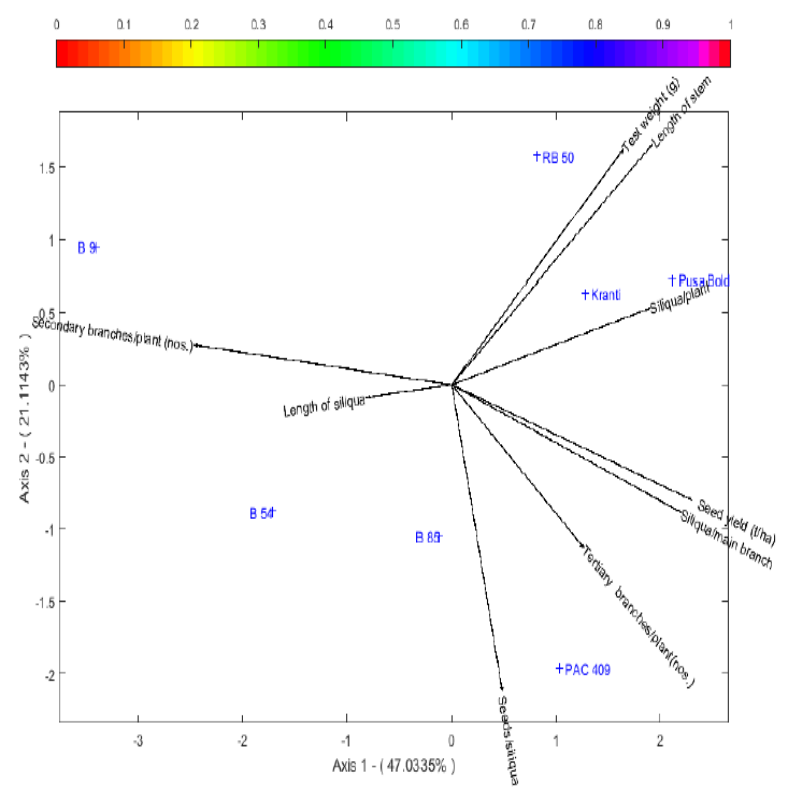

Fig. 1. Scattered plot matrix score of rapeseed-mustard cultivars and associated traits.

Table 1. Meteorological variables during rapeseed-mustard growing seasons.

\begin{tabular}{llllll}
\hline Growing season & Month & $\boldsymbol{T}_{\max }\left({ }^{\circ} \mathbf{C}\right)$ & $\boldsymbol{T}_{\boldsymbol{m i n}}\left({ }^{\circ} \mathbf{C}\right)$ & Relative humidity $(\%)$ & Rainfall (mm) \\
\hline Winter 2013-14 & December & 26.2 & 13.3 & 87.2 & 0 \\
& January & 24.4 & 11.5 & 88.3 & 0 \\
& February & 26.8 & 15.1 & 86.7 & 0 \\
& March & 31.8 & 20.6 & 87.2 & 0 \\
Winter 2014-15 & December & 25.9 & 12.6 & 78.2 & 0 \\
& January & 24.9 & 12.3 & 77.1 & 3 \\
& February & 27.6 & 16.1 & 76.3 & 0 \\
& March & 32.1 & 20.5 & 73.4 & 36.6 \\
\hline
\end{tabular}

$T_{\max }$ and $T_{\min }$ represent maximum and minimum temperatures, respectively

Table 2. Salient features of different rapeseed-mustard cultivars used for the study and their source of collection.

\begin{tabular}{|c|c|c|c|c|c|c|}
\hline Cultivars & Category & Scientific name & $\begin{array}{l}\text { Days to har- } \\
\text { vest (nos.) }\end{array}$ & $\begin{array}{l}\text { Seed } \\
\text { colour }\end{array}$ & $\begin{array}{l}\text { Oil con- } \\
\text { tent }(\%)\end{array}$ & Source \\
\hline B-54 & Toria & $\begin{array}{l}\text { Brassica napus var. } \\
\text { toria }\end{array}$ & 90 & Brown & 38 & $\begin{array}{l}\text { PORS*, Berhampore, } \\
\text { West Bengal }\end{array}$ \\
\hline RB-50 & Rai / Indian mustard & Brassica juncea & 107 & Brown & $38-40$ & $\begin{array}{l}\text { PORS*, Berhampore, } \\
\text { West Bengal }\end{array}$ \\
\hline Pusa Bold & Rai / Indian mustard & Brassica juncea & 107 & Brown & 40 & $\begin{array}{l}\text { PORS*, Berhampore, } \\
\text { West Bengal }\end{array}$ \\
\hline PAC-409 & Yellow sarson & $\begin{array}{l}\text { Brassica napus var. } \\
\text { glauca }\end{array}$ & 110 & Yellow & 45 & $\begin{array}{l}\text { PORS*, Berhampore, } \\
\text { West Bengal }\end{array}$ \\
\hline B-9 & Yellow sarson & $\begin{array}{l}\text { Brassica napus var. } \\
\text { glauca }\end{array}$ & 90 & Yellow & 46 & $\begin{array}{l}\text { PORS*, Berhampore, } \\
\text { West Bengal }\end{array}$ \\
\hline Kranti & Rai / Indian mustard & Brassica juncea & 110 & Brown & 40 & $\begin{array}{l}\text { PORS*, Berhampore, } \\
\text { West Bengal }\end{array}$ \\
\hline B-85 & Rai / Indian mustard & Brassica juncea & 95 & Brown & 38 & $\begin{array}{l}\text { PORS*, Berhampore, } \\
\text { West Bengal }\end{array}$ \\
\hline
\end{tabular}

"based on present experimental data, *Pulses and Oilseeds Research Station 
tested using Bartlett's $\chi^{2}$ test. As the error variance was homogeneous, pooled analysis was done. The Duncan's multiple range test (DMRT) was applied to determine the least significant difference (LSD) at $p \leq$ 0.05 unless otherwise mentioned (Duncan, 1955). The Pearson's correlation coefficients were calculated to describe the degree and pattern of associations of observed traits of cultivars. Direct and indirect path coefficients were calculated for quantitative traits using the software OPSTAT, as proposed by Sheoran et al. (1998). For path analysis of quantitative traits, seed yield was considered as response variable whereas plant height $(\mathrm{PH})$, dry matter (DM), fertile plants (FP), days to $50 \%$ flowering (DTFPF), days to $100 \%$ flowering (DTHPF), days to harvest (DTH), secondary branches/plant (SBP), tertiary branches/plant (TBP), length of stem upto starting point of siliqua (LSSPS), siliqua/plant (SP), siliqua in main branches (SMB), length of siliqua (LS), seeds/siliqua (SS), and test weight (TW) were considered as causal variable.

\section{RESULTS AND DISCUSSION}

Characterization of cultivars using phenotypic traits: Combined analysis of data revealed that cultivar $\times$ year interaction was not significant at $5 \%$ probability level, which indicates that cultivars responded similarly to weather condition in both the years (data not shown). The ANOVA revealed that the assessments were significant for all the traits at $0.1 \%$ probability level, except for three traits, namely, fertile plants $/ \mathrm{m}^{2}$, secondary branches/plant and length of stem up to starting point of siliqua, which were significant at $1 \%$ probability level (Table 3 ). This suggests that there is genetic diversity among tested rapeseedmustard cultivars for all these traits under study.

Mean performance and rank amongst the rapeseedmustard cultivars are summarized in Table 4 and Table 5. Promising cultivars were identified considering three important yield-attributing traits, namely, dry matter, siliqua/plant and 1000 seed weight. Top three ranking cultivars based on dry matter accumulation were RB50, PAC-409 and Pusa Bold. Dry matter accumulation at harvest among these cultivars ranged from 504 to $643 \mathrm{~g} / \mathrm{m}^{2}$. Cultivars that produced the highest siliqua/ plant were RB-50, PAC-409 and Pusa Bold. Number of siliqua/plant ranged from 254 to 295. Best three cultivars based on1000 seed weight were Kranti, Pusa Bold and RB-50. Test weight among these cultivars ranged from 5.24 to $6.65 \mathrm{~g}$. Consequently, these three discussed traits were supposed to have a positive influence on seed yield of rapeseed-mustard cultivars. The results confirm observations of Mandal and Sinha (2004), Gangapur et al. (2009) and Rathore et al. (2015) who concluded that increasing yield attributes mainly dry matter, siliqua/plant and 1000 seed weight would be a good combination to obtain high seed yield.
These yield attributes have been extensively used to compare different species or cultivars at different agroecological situations.

Growth parameters: For all the tested cultivars, plant height increased as the age of the crop progressed up to maturity. Plant height recorded at different interval was significantly $(p \leq 0.05)$ influenced by the cultivar (Table 6). At harvest, PAC-409 produced taller plants, followed by Pusa Bold. Lowest plant was recorded in B-9. Irrespective of cultivars, dry matter accumulation increased steadily up to 90 DAS, and finally decreased at harvest, showing significant effect between cultivars (Table 6). Till at harvest, it was significantly higher for the cultivar RB-50, followed by PAC-409. Vegetative growth of the plants was poor in B-54, resulting in significantly $(p \leq 0.05)$ lower dry weight of above ground biomass. Till harvest, significant variations were observed in number of fertile plant $/ \mathrm{m}^{2}$. The cultivar B-54 produced higher number of fertile plant/ $\mathrm{m}^{2}$, closely followed by B-85 and Kranti. On the other hand, number of fertile plant $/ \mathrm{m}^{2}$ decreased significantly in PAC-409 and Pusa Bold as compared to the rest of cultivars. Cultivar exerted significant $(p \leq 0.05)$ variation on the flowering behavior (Table 6). The cultivar B-54 attained 50 and $100 \%$ flowering early while Pusa Bold took maximum time to complete $100 \%$ flowering. Both PAC-409 and Kranti took maximum time (100 days) to reach at harvest maturity, while B-54 and B-9 were ready for harvesting too early (90 days) when compared with other cultivars under study.

Yield and its attributes: Early maturing cultivars namely B-9, B-54 produced relatively higher number of secondary branches per plant, followed by RB-50. Similar was in case for tertiary branch production where the maximum number was produced by B-54, closely followed by B-85 and RB-50 (Table 7). The cultivar RB-50 proved its superiority over all other tested cultivars by producing significantly $(\mathrm{p} \leq 0.05)$ higher number of siliqua per plant, closely followed by PAC-409 and Pusa Bold. Early maturing cultivars like B-9, B-54 and B-85 produced lower number of siliqua per plant. Number of siliqua on branch considered being one of the most important yield-determining factors in rapeseed-mustard, and this was higher in Pusa Bold, PAC 409 and Kranti. The tested cultivars showed significant difference in length of stem up to starting point of siliqua. The cultivar Pusa Bold achieved maximum length of stem up to starting point of siliqua, and it was statistically at par with the length attained by Kranti and RB-50. Significant $(\mathrm{p} \leq 0.05)$ variation was also observed for length of siliqua among the tested cultivars. The cultivar Kranti produced longest siliqua, closely followed by those produced by B-54 and B-9. The pooled data on seeds per siliqua (nos.) of rapeseed-mustard showed that cultivars fail to show any significant variation among 
Hirak Banerjee et al. / J. Appl. \& Nat. Sci. 9 (2): 940 - 949 (2017)
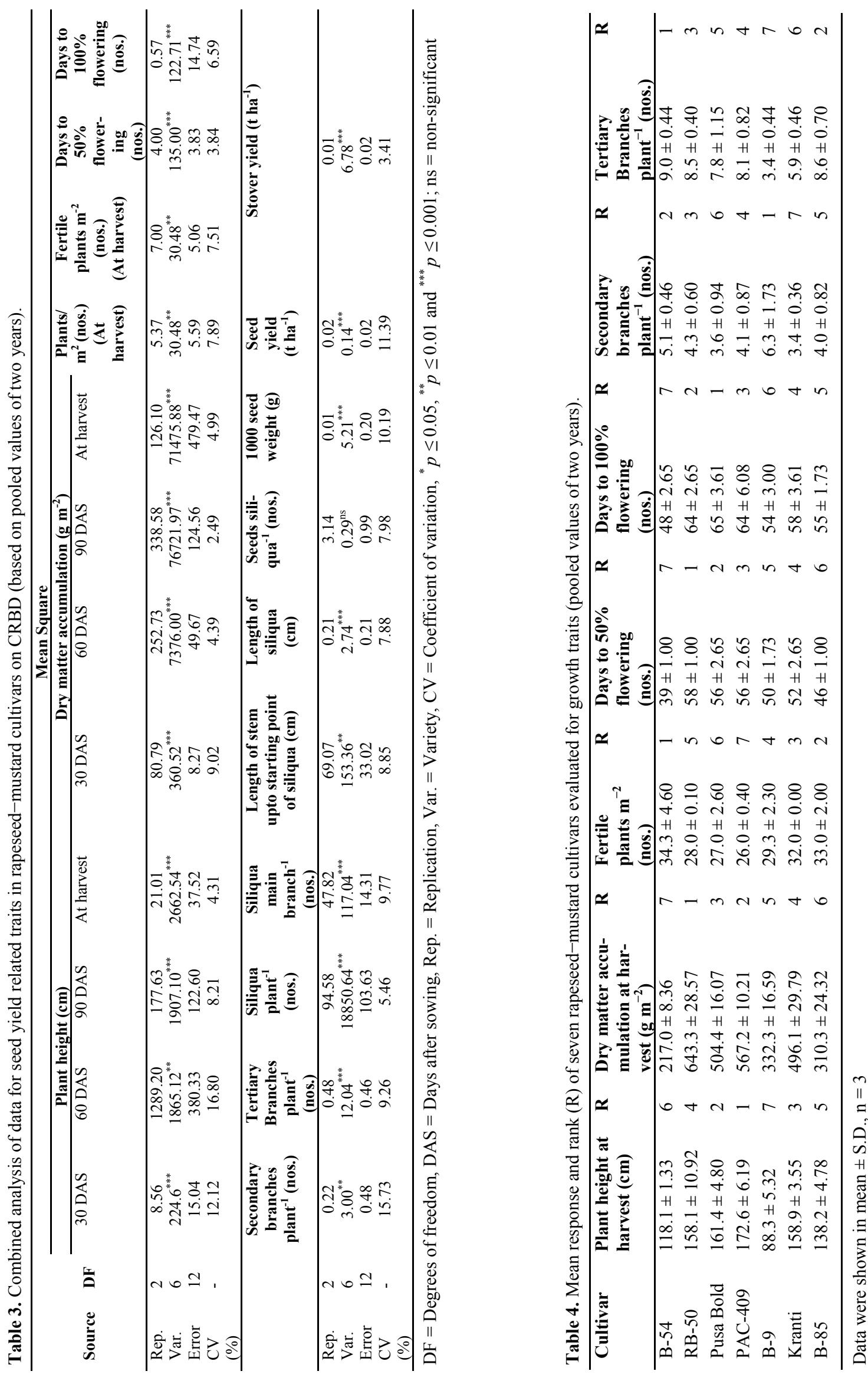
Hirak Banerjee et al. / J. Appl. \& Nat. Sci. 9 (2): 940 - 949 (2017)
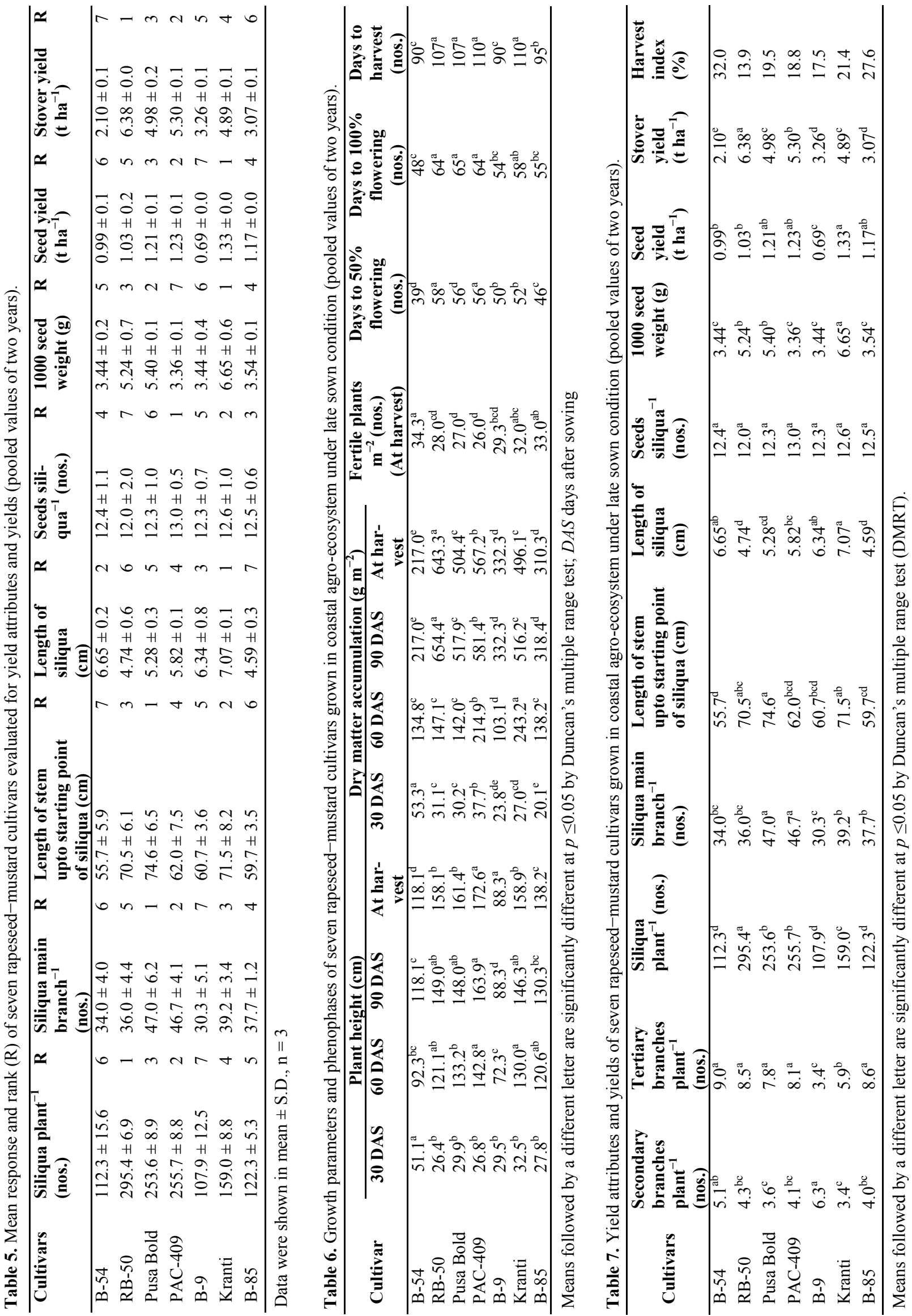
Hirak Banerjee et al. / J. Appl. \& Nat. Sci. 9 (2): 940 - 949 (2017)

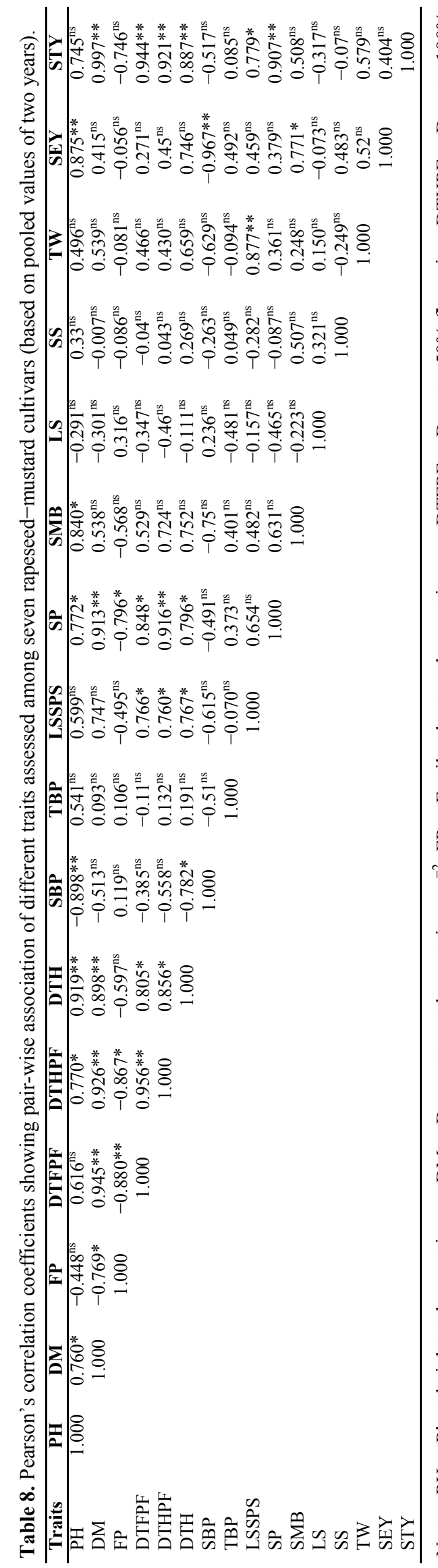

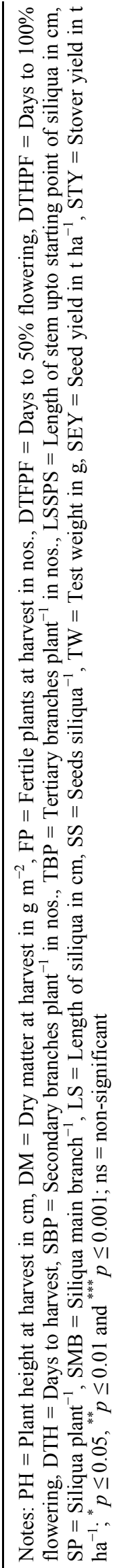

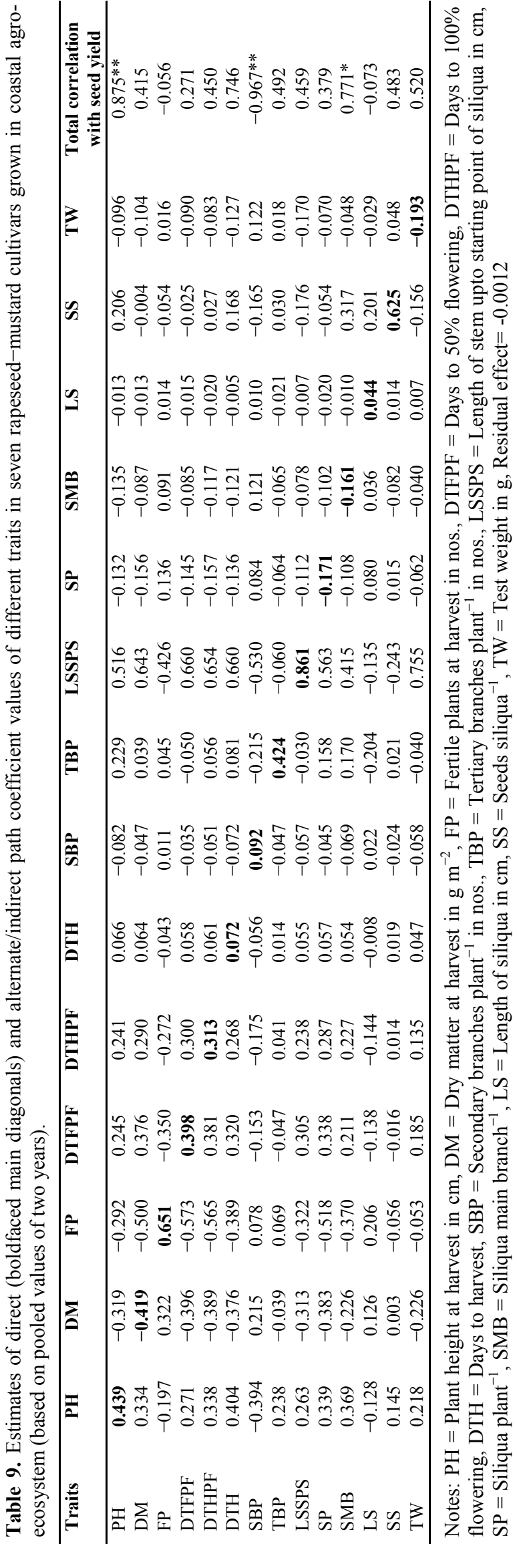


them. However, there were significant differences in test weight among the studied cultivars and Kranti was recorded with highest mean test weight. Additionally, Kranti documented significantly $(\mathrm{p} \leq 0.05)$ higher seed yield, closely followed by PAC-409 and Pusa Bold; though the cultivar RB-50 produced significantly $(\mathrm{p} \leq 0.05)$ higher stover yield followed by PAC -409 and Kranti (Table 7). Cultivars under study showed variations in harvest index, and it was maximum in B54 followed by B-85. A better harvest index is indicative of a shift in conversion of complex carbohydrate into simpler form and its mobilization towards increased sink capacity (Mishra et al., 2014).

Correlation analysis: Pearson correlation coefficients showing pair-wise associations between the assessed traits of the cultivars are presented in Table 8. Among the quantitative traits evaluated, significant and positive correlations were observed between $\mathrm{PH}$ and DM $(r=0.76, p \leq 0.05)$, DTHPF $(r=0.77, p \leq 0.05)$, DTH $(r=0.92, p \leq 0.01)$, SP $(r=0.77, p \leq 0.05)$, SMB $(\mathrm{r}=0.84, \mathrm{p} \leq 0.05)$ and $\operatorname{SEY}(\mathrm{r}=0.88, \mathrm{p} \leq 0.01)$. DM showed highly significant and positive correlation $(\mathrm{p} \leq$ $0.01)$ with DTFPF $(r=0.95)$, DTHPF $(r=0.93)$, DTH $(\mathrm{r}=0.89)$, SP $(\mathrm{r}=0.91)$ and STY $(\mathrm{r}=0.99)$. Significant and positive correlations were observed between DTFPF $(r=0.96, p \leq 0.01)$, DTH $(r=0.81, p$ $\leq 0.05), \operatorname{LSSPS}(\mathrm{r}=0.77, \mathrm{p} \leq 0.05)$, SP $(\mathrm{r}=0.85, \mathrm{p} \leq$ $0.05)$ and STY $(r=0.94, p \leq 0.01)$. Similarly, DTHPF was significantly and positively correlated with DTH $(r=0.86, p \leq 0.05)$, LSSPS $(r=0.76, p \leq 0.05)$, SP $(r$ $=0.92, \mathrm{p} \leq 0.01)$ and STY $(\mathrm{r}=0.92, \mathrm{p} \leq 0.01)$. Significant and positive correlations were observed between DTH and LSSPS $(r=0.77, \mathrm{p} \leq 0.05)$, SP $(\mathrm{r}=$ $0.80, \mathrm{p} \leq 0.05)$ and STY $(\mathrm{r}=0.89, \mathrm{p} \leq 0.01)$. Also significant and positive correlations were detected between LSSPS and TW $(r=0.88, \mathrm{p} \leq 0.01)$ and STY $(\mathrm{r}=0.78, \mathrm{p} \leq 0.05)$. Significant and positive correlations were also observed between SP and STY $(\mathrm{r}=0.91, \mathrm{p} \leq 0.01)$, and SMB and SEY $(\mathrm{r}=0.77, \mathrm{p} \leq$ $0.05)$.The significant and positive association within the above mentioned attributes is rational in plants with indeterminate growth habit (rapeseed-mustard for instance) where it is challenging to confirm the date of maturity. The strong relationships among these characters in the present study indicated that these characters were governed by the same genetic system i.e. the characters were expected to be linked with each other and they should be given high priority during selection of high yielding genotypes of rapeseedmustard. Singh et al. (2003) and Lodhi et al. (2014) also observed such positive association of SEY with SMB and PH (main shoot length). Generally, the positive associations among these three traits suggest the prospect of improving these important yieldattributing characters concurrently. It was observed that DTFPF showed positive and significant correlation with SEY in our study that disagreed with
Shekhawat et al. (2014) who reported that DTFPF contributed negative correlation with seed yield of Indian mustard and its direct effect $(-0.092)$ on seed yield per plant was also negative.

On the other hand, significant and negative correlations were observed between PH and SBP $(r=-0.90, p \leq$ $0.01)$, besides DM and FP $(\mathrm{r}=-0.77, \mathrm{p} \leq 0.05)$. Likewise, FP was significantly and negatively correlated with DTFPF $(\mathrm{r}=-0.88, \mathrm{p} \leq 0.01)$ and DTHPF $(r=-0.87, p \leq 0.05)$. Significant and negative correlations were observed between DTH and SBP $(r=$ $-0.78, \mathrm{p} \leq 0.05)$, plus SBP and SEY $(\mathrm{r}=-0.97, \mathrm{p} \leq$ 0.05 ). It was most interesting to observe that number of FP showed negative association with DM, DTFPF and DTHPF as well. Hence, to attain maximum FP, the genotype(s) with early maturity should be considered during varietal selection for coastal saline zone in particular. Further, SBP (that is considered as an important vegetative attribute) negatively influenced the FP or eventually seed yield signifying the dry matter partitioning between vegetative and reproductive phases of any plant species in general. Opposing to our study, Ramanjaneyulu and Giri (2007), reported significant positive association between SBP and SEY in Indian mustard, which was supported later by Lodhi et al. (2014). Surprisingly, SP, being an imperative yield attributing character, didn't show any significant correlation neither to SEY or STY in our study. Generally, the positive association between SP and SEY was reported in ample of publications in Indian mustard (Akbar et al., 2003; Hasan et al., 2014; Shekhawat et al., 2014), nevertheless, with exceptions by Gangapur et al. (2009) and Lodhi et al. (2014).

Path coefficient analysis of various traits in rapeseed-mustard: direct and indirect effects: With the aim of analyzing the genetic correlations further and splitting the correlation coefficient into direct and indirect influences of different attributes, path coefficient technique was employed. It therefore warrants an acute study of attributes those affect a certain correlation and can be advantageous in preparing a competent selection approach (Scheiner et al., 2000). Results on the path coefficients with seed yield as the response variable are summarized in Table 9. Values of direct effects were $<1$, indicating that inflation due to multicollinearity was low. Among the growth and yield components, $\mathrm{PH}(0.875)$ followed by SMB (0.771) exhibited highly positive direct effects on seed yield of rapeseed-mustard (Table 9). The direct selection for these two characters could be beneficial for yield improvement of rapeseed-mustard since these characters also showed positive correlation with seed yield. Other growth attributes and yield-determining traits exerted either negligible or low or negative direct effects on seed yield. Selection based on these characters will not improve yield of rapeseed-mustard. 
Residual effect was very low (-0.0012) suggesting inclusion of maximum seed yield influencing characters of rapeseed-mustard in the present analysis. Path coefficient analysis is increasingly being used in plant breeding (Samonte et al., 1998). There are scanty of studies on agronomic traits in rapeseed-mustard to identify the preeminent selection standards linked to increased yield and the other attributes that influence it. Earlier, Pandey and Singh (2005), Verma et al. (2008), and Lodhi et al. (2014) reported maximum positive direct influence of $\mathrm{PH}$ and SMB on seed yield in case of Indian mustard. The observed two specific traits (PH and SMB), in our study, with superior genetic variability, heritability, higher expected genetic gain under selection and are considerably correlated with seed yield can consistently be employed for enhancement of seed yield via ancillary selection.

Step-wise regression equations of prime contributing traits affecting seed yield of mustard: Regression analysis of seed yield as a dependent variable showed that trait like number of secondary branches/ plant had negative and seeds/siliqua had positive significant relationship with yield. Therefore, higher values of these traits would decrease and increase seed yield, respectively. Standard equations of regression were:

Seed yield $=1.998-0.206$ number of secondary branches/plant ${ }^{* *}$

Seed yield $=-0.156-0.192$ number of secondary branches/plant $^{* * *}+0.168$ seeds/siliqua ${ }^{* *}$

Diversity analysis: Biplot analysis was used to identify the cultivars most superior for an individual trait or set of traits (Figure 1).The scattered plot matrix score clustered the cultivars into groups showing superiority with a set of morphological traits. Both B-54 and B-85 were the most superior cultivars for length of siliqua and seeds/siliqua. The cultivars B-9 and RB-50 were characterized by more number of secondary branches/ plant and test weight. The cultivars Kranti and Pusa Bold had greater length of stem up to starting point of siliqua and number of siliqua/plant. On the other hand, PAC-409 is a single cultivar characterized by higher number of tertiary branches/plant and seeds/siliqua. This classification is not in exact, but in accordance with the cluster analysis generated employing single linkage using the same data for potato crop (Biniam et al., 2015).

\section{Conclusion}

Productivity and profitability of rapeseed-mustard in the major production domain of West Bengal could be increased through the cultivation of improved varieties using site-specific approach. Our results revealed that higher seed yield could be obtained with Kranti followed by PAC-409 and Pusa Bold in coastal ecosystem of West Bengal, particularly under late sown condition (December $1^{\text {st }}$ week sowing) on account of late harvesting of preceding kharif paddy. Moreover, the adoption of any recommendation depends upon its economic viability. Hence, economic assessment revealed that the maximum net return (Rs. 23651/- per hectare) was recorded with Kranti due to higher seed yield. Higher benefit-cost ratio (1.57) was obtained with Kranti followed by PAC-409 and Pusa Bold. The results also indicated that number of secondary branches/plant had negative and seeds/ siliqua had positive significant relationship with seed yield of rapeseed-mustard.

\section{ACKNOWLEDGEMENTS}

This research was supported by grants from the Bhabha Atomic Research Centre (BARC) of India. The authors are grateful to Bidhan Chandra Krishi Viswavidyalaya, India for providing necessary technical support during the course of investigation. We thank Mr. Gurupada Khanra and Mr. Ajay Kar for their assistance in the farm work during the crop growth period.

\section{REFERENCES}

Akbar, M., Mahmood, T., Yaqub, M., Anwar, M., Ali, M. and Iqbal, N. (2003). Variability, Correlation and Path Coefficient Studies in Summer Mustard (Brassica juncea L.). Asian J. Plant Sci., 2(9): 696-698

Berger, K. C. and Truog, E. (1939). Boron determination in soils and plants. Industrial and Engineering Chemistry, Analytical Edition, 11: 540-545

Biniam, M. G., Githiri, S. M., Tadesse, M., and Kasili, R. W. (2015). Analysis of diversity among potato accessions grown in Eritrea using single linkage clustering. Am. $J$. Plant Sci., 6: 2122-2127

Crop Production Statistics Information System. (2016). Special Data Dissemination Standard Division, Directorate of Economics \& Statistics, Ministry of Agriculture and Farmers Welfare, Govt. of India, New Delhi. Available from URL: (http://aps.dac.gov.in/APY/Index.htm). Accessed on 11 August 2016.

De, B., Das, B., Das, B. and Sinha, A. C. (2014). Effect of integrated nutrient management on yield, nutrient uptake and economics of rapeseed (Brassica campestris var. yellow sarson) in terai region of West Bengal. $J$ Crop and Weed, 10(1): 69-72

Directorate of Agriculture. (2015). Economic Review, Statistical Appendix 2014-15, Directorate of Agriculture, Government of West Bengal, Kolkata, India.

Duncan, D.B. (1995) Multiple range and multiple F tests, Biometrics, 11: 1-42

Economic Review. (2015). Statistical Appendix. Department of Statistics and Programme Implementation. Government of West Bengal, India, Pp. 65

Gangapur, D. R., Prakash, B. G., Salimath, P. M., Ravikumar R. L. and Rao M. S. L. (2009). Correlation and path analysis in Indian mustard (Brassica juncea L. Czern and Coss). Karnataka J. Agric. Sci., 22(5): 971-977

Hasan, E. U., Mustafa, H. S. B., Bibi, T. and Mahmood, T. (2014). Genetic Variability, Correlation And Path Anal- 
ysis in Advanced Lines of Rapeseed (Brassica napus L.) for Yield Components. Cercetări Agronomice în Moldova, 47(1): 71-79

Hassan, S. M. F., Iqbal, M. S., Rabbani, G., Naeem-ud-Din, Shabbir, G., Riaz, M. and Noorka, I. R. (2013). Correlation and path analysis for yield and yield components in sunflower (Helianthus annus L.). African J. Biotech., 12(16): 1968-1971

Lodhi, B., Thakral, N. K., Avtar, R. and Singh, A. (2014). Genetic variability, association and path analysis in Indian mustard (Brassica juncea). J. Oilseed Brassica, 5(1): $26-31$

Mandal, K. G. and Sinha, A. C. (2004). Nutrient Management Effects on Light Interception, Photosynthesis, Growth, Dry matter Production and Yield of Indian Mustard (Brassica juncea). J. Agronomy and Crop Science 190(2): 119-129

Mashilo, J., Shimelis, H. and Odindo, A. (2016). Correlation and path coefficient analysis of qualitative and quantitative traits in selected bottle gourd landraces. Acta Agr. Scand. B-S-P., 66(7): 558-569

Mishra, J. S., Thakur, N. S., Singh, P., Kubsad, V. S., Kalpana, R., Alse, U. N. and Nemade, S. M. (2014). Tillage and integrated nutrient management in rainy-season grain sorghum (Sorghum bicolor). Indian J. Agron., 59 (4): 619-623

Pandey, S and Singh, Basudeo. (2005). Inter character association and path analysis in Indian mustard [Brassica juncea (L.) Czern. \& Coss.]. Adv. Plant Sci., 18: 511514

Ramanjaneyulu, A. V. and Giri, G., (2007). Correlation and path coefficient analysis in Indian mustard [Brassica juncea (L.) Czern \& Coss]. The J. Res. ANGRAU, 35: $107-110$

Rathore, S. S., Shekhawat, K., Meena, A. and Singh, D. (2015). Growth, productivity and economics of coral432 (Indian mustard hybrid) under different cropping systems. J. Oilseed Brassica, 6(1): 202-208

Ray, K, Sengupta, K., Pal, A. K. and Banerjee, H. (2015). Effects of sulphur fertilization on yield, S uptake and quality of Indian mustard under varied irrigation regimes. Plant Soil Environ., 61(1): 6-10

Ray, K., Banerjee, H., Paul, T. and Das, T. K. (2016). Irrigation and sulphur fertilization effects on the productivity, profitability and greenhouse gases emissions in Indian mustard. Exp. Agr., 52(3): 434-446

Ray, K., Dutta, J., Banerjee, H., Biswas, R., Phonglosa, A. and Pari, A. (2014a). Identification of principal yield attributing traits of Indian mustard [Brassica juncea (L.) Czernj and Cosson] using multivariate analysis. The Bioscan 9(2): 803-809
Ray, K., Pal, A. K., Banerjee, H. and Phonglosa, A. (2014b). Correlation and path analysis studies for growth and yield contributing traits in Indian mustard (Brassica juncea L.). Int. J. Bio-resource and Stress Manage., 5 (2): 200-206

Samonte, S. O. P. B., Wilson, L. T. and McClung, A. M. (1998). Path analysis of yield and yield related traits of fifteen diverse rice genotypes. Crop Sci., 38: 1130-1136

SAS Institute. (2011). The SAS System for Windows. Release 9.3. SAS Institute, Cary, NC.

Scheiner, S. M., Mitchell R. J. and Callahan, H. S., (2000). Using path analysis to measure natural selection. Journal of Evolutionary Biology, 13: 423-433

Shah, M. S., Verma, N. and Vishwkarma, S. K. (2015). Diversification of rice (Oryza sativa)-based cropping system for higher production efficiency, water productivity and economic viability in Madhya Pradesh. Indian $J$. Agron., 60(1): 5-30

Shekhawat, N., Jadeja, G. C., Singh J. and Shekhawat, R. S. (2014). Character Association Studies Among Yield And Its Component Characters in Indian Mustard (Brassica juncea L. Czern \& Coss). The Bioscan. 9(2): 685-688

Sheoran, O. P., Tonk, D. S., Kaushik, L. S., Hasija, R. C. and Pannu, R. S. (1998). Statistical Software Package for Agricultural Research Workers. Recent Advances in information theory, Statistics \& Computer Applications (Eds. D. S. Hooda and R. C. Hasija). Department of Mathematics Statistics, CCS HAU, Hissar. Pp. 139-143

Sheoran, P., Sardana, V. and Singh, R. (2014). Evaluating productivity potential of spring planted sunflower (Helianthus annuus) hybrids in response to sowing time under changing climate scenario. Indian J. Agron., 59 (1): $124-132$

Shimelis, H. and Hugo, A. (2011). Determination of selection criteria for seed yield and seed oil content in Vernonia (Vernonia galamensis variety ethiopica). Ind. Crop. Prod., 33: 436-439

Singh, M., Srivastava, R. L., Prasad, L. and Dixit, R. K. (2003). Correlation and path analysis in Indian mustard [Brassica juncea (L.) Czern \& Coss]. Adv. Plant Sci., 16: 311-315

Singh, R. K., Singh, Y., Singh, A. K., Kumar, R. and Singh, V. K. (2010). Productivity and economics of mustard (Brassica juncea) varieties as influenced by different fertility levels under late sown condition. Indian $J$. of Soil Conservation. 38(2): 121-124

Verma, R., Sharma, R. and Sharma, S. K. (2008). Association studies among yield and its component characters in Indian mustard [Brassica juncea (L.) Czern \& Coss]. Indian J. Genet. Plant Breed., 68: 87-89 